Global Conferences Series:

Sciences and Technology (GCSST), Volume 3, 2020

The $1^{\text {st }}$ International Conference on Education, Sciences and Technology

DOI: https://doi.org/10.32698/tech3233

\title{
The Relationship Between Mathematical Literacy and Gender with Financial Literacy
}

\author{
I Gusti Putu Suharta, I Made Suarjana, Ni Nyoman Parwati \\ Universitas Pendidikan Ganesha, Indonesia \\ *putu.suharta@undiksha.ac.id
}

\begin{abstract}
Literacy is the core of education for all. Therefore, Mathematical Literacy and Financial Literacy must be an important part of the Undiksha Mathematics Education Study Program (UMESP) Students. This study aims to describe Mathematical Literacy and Financial Literacy, and determine the relationship between Mathematical Literacy and Gender with Financial Literacy of UMESP students. This type of research uses ex post facto design, with the population being UMESP students who have taken Financial Mathematics and Linear Programs Courses in 2018 and the samples are determined by random sampling technique. The instruments and data collection techniques used were questionnaires and tests. Then the data were analyzed using Regresion and Chi Square. The results of the study are: (1) Mathematical Literacy and Financial Literacy of UMESP students are medium classification. and (2) Mathematical Literacy and Gender, both simultaneously and partially have no effect on Financial Literacy. Age, education level of parents, type of parents work, and living costs have a significant influence on gender.
\end{abstract}

Keywords: Mathematical Literacy, Financial Literacy, Gender

\section{Introduction}

According to Wagner, DA (2011), literacy is the core of education for all. Similarly, Financial Literacy and Mathematics Literacy are important aspects of mathematics education. In 2012 the Programme for International Student Assessment (PISA) research on children, aged 15 in 18 countries in the world, showed, only $15 \%$ students are able to distinguish among needs and desires, make simple decision about daily expenses, recognize general financial purposes and apply numeric operation in an individual context. Another result, there is no difference in Financial Literacy based on the gender, except in Italy, where male students have higher score than female students (OECD, 2014).

In 2016, Indonesia Otoritas Jasa Keuangan (OJK) surveyed 9680 respondents from 34 provinces and 64 regencies / cities. It showed that Indonesia Financial Literacy Index is $29.66 \%$ and Bali Financial Literacy Index is $37.45 \%$. Only $36.02 \%$ of people claim to be able in calculating interest, installment, investment result, inflation, fine, and product usage cost. Short term goal, like fulfilling daily needs and survival, dominated people financial goal (OJK, 2016). 
As is the case in mathematics education, Mathematics Literacy must be the core of mathematics learning. Mathematical Literacy is the ability of individuals to formulate, apply, and interpret mathematics in various contexts. This capability includes mathematical reasoning and the ability to use facts, concepts, and mathematical procedures to describe, explain and predict a phenomenon (OECD, 2013). The results of the study on Mathematics Literacy of Indonesian students are low (OECD, 2013; Mahdiansyah and Rahmawati,2014; Suharta and Suarjana ,2018) .

In general, Bali applies patriarch system. It considers men superiority to women because they continue the clan (purusa). The patriarch culture shaped traditional gender behavior on people. In traditional gender role, men are regarded superior to women. In Pakistan, Farah Javed and Samreen Lodhi (2015) studied about gender related matters and found that gender had no role in financial decision making, but culture factor influenced on avoiding the risk behavior. Therefore, it is very interesting to study the relationship between Mathematical Literacy and Gender with Financial Literacy so as to provide initial knowledge in the development of Financial Mathematics education.

OECD(2014) define Financial Literacy as an ability to use knowledge and skill for managing financial or its resources and arrange both long and short term financial plans to improve economic condition. In line with the definition, Financial Literacy has knowledge and application aspect. Huston (2010), Atkinson and Messy (2012) stated:

- Knowledge dimension. It includes financial knowledge from education or experience related to personal financial product and concept.

- Application dimension. It reflects ability and confidence to apply the knowledge efficiently.

According to OECD (2014), Financial Literacy Framework in PISA 2012 consists of content, process and context.Content category. Content category it consists of knowledge and comprehension which play important role in financial literacy. They are money and transaction, financial planning and management, risk and award, and financial landscape. Process category. It consists of financial information identification; information analysis in financial context, financial problem evaluation and financial knowledge, and understanding application. Context category. It covers education and occupation, home and family, individual and society.

According to OECD (2013) Mathematical literacy is an individual's capacity to formulate, employ, and interpret mathematics in a variety of contexts. It includes reasoning mathematically and using mathematical concepts, procedures, facts, and tools to describe, explain, and predict phenomena. It assists individuals to recognise the role that mathematics plays in the world and to make the wellfounded judgments and decisions needed by constructive, engaged and reflective citizens. In accordance with this, then Mathematical literacy is related to : (1) a person's ability to formulate, use, and interpret mathematics in a variety of contexts, (2) using mathematical reasoning, concepts, procedures, facts, and tools to describe, explain, and predict phenomena, and (3) providing benefits about the role of mathematics in the real world.

This is in accordance with OECD (2010) which states that the Mathematical Literacy construction developed by PISA consists of (3C), i.e. Content, Context, and Competence. On content, PISA divides it into 4 parts as following: Change and relationship, Space and Shape,Quantit, Uncertainty and dat $a$. The questions on PISA involve four Contexts, namely relating to Personal, Occupational, Societal, and Scientific . Menurut OECD (2010), competence in PISA are called competency clusters, consisting of Knowledge Competencies, using Routine Procedures, using Multistep Procedures, and Reasoning. 
Gender bias on financial will affect financial literacy. (Lemaster,P and JoNell Strough, 2014) acquired, men are more tolerant to risk and more confidence in investment. More often than not, women communicate with their couple in investment decision making, but men hardly ever do it. The men confidence on investment is higher than women. Investment decision making consumes more time, tiresome and difficult job. Cautiousness and low risk tolerance level make women require more time to decide an investment.

\section{Research Method}

As the dependent variable is Financial Literacy, while the independent variable is Mathematical Literacy and Gender. As a population, there are UMESP students in 2018 who have taken courses in Financial Mathematics and Linear Programs. The population is 99 people. The size of the study sample was determined using the Slovin's formula to obtain a sample of 80 people. Next, the sample is determined by random sampling technique.

The instruments and data collection techniques in this study used questionnaires and tests. Questionnaires are used to measure gender and Financial Literacy, while tests are used to measure mathematical Literacy. The Financial Literacy Questionnaire used refers to the instrument used by PISA (OECD, 2014), while the Mathematical Literacy test is taken from the PISA test (OECD, 2010) with the number of questions 3 relating to numbers, functions and algebra, and statistics and the context of Mathematical Literacy and Finance Literacy classification uses conversion as follows.

Table 1: Conversion of Mathematical Literacy and Finance Literacy

\begin{tabular}{ll}
\hline Average Scor & Classification \\
\hline Average Score $\geq 80 \%$ & High \\
If $\leq 60 \%$ of average Score $<80 \%$ & Medium \\
Average Score $<60 \%$ & Low \\
\hline
\end{tabular}

(Haşmet Sarıül, 2014)

The research applies regression analysis to determine Mathematical Literacy and gender contribution to Financial Literacy

\section{Research Results and Discussion}

The characteristics of the research sample and financial literacy were collected by questionnaire. The first part of the questionnaire relates to sample characteristics such as sex, age, parental education, parental work, and living expenses in a month. Questionnaire second part deals with financial literacy. In this case there are 13 statements with general gradations: strongly disagree, disagree, agree, and strongly agree. Positive stem scores are 1-4, while negative ones are reversed, 4-1. Thus the maximum score of financial literacy is $13 \times 4=52$.

Mathematical Literacy is measured using tests taken from PISA questions. The number of questions is 3 , and each number is given a maximum score of 10, so the maximum score of Mathematical Literacy is 30. All scores both Financial Literacy and Mathematical Literacy are converted to a scale of 100. In general the sample characteristics are female dominant (66.25\%), aged between 18-20 years old at $95 \%$, the education level of his parents is high school of $43.75 \%$, and the dominant type of work for parents is besides being a teacher, TNI / POLRI, office / entrepreneurial employees which is $38.75 \%$, and costs dominant student life is below 2 million, which is $92.5 \%$. The research results relating to Mathematics and Financial Literacy are presented in the following table. 
Table 2: Classification of Mathematical Literacy and Financial Literacy

\begin{tabular}{cccccc}
\hline No. & Literacy & Average & High & Medium & Low \\
\hline 1 & Mathematical Literacy & 69.38 & $37.5 \%$ & $31.25 \%$ & $31.25 \%$ \\
2 & Financial Literacy & 72.12 & $12.5 \%$ & $82.5 \%$ & $5 \%$ \\
\hline
\end{tabular}

Table 2 shows average Mathematical Literacy is 69.38 and average financial literacy is 72.12 . It means the Mathemayical Literacy and Financial Literacy is medium classification. To see the relationship between Mathematical Literacy and Gender with Financial Literacy analyzed using regression analysis. The summary of the regression analysis results are as follows.

Table 3a. Model Summary Anareg

Model Summary

\begin{tabular}{ccccc}
\hline Model & $\mathrm{R}$ & $\mathrm{R}$ Square & Adjusted R Square & Std. Error of the Estimate \\
\hline 1 & $.320^{\mathrm{a}}$ & .102 & .067 & 6.45651 \\
\end{tabular}

Table 3b. Anova

ANOVA $^{\mathrm{a}}$

\begin{tabular}{|c|c|c|c|c|c|c|}
\hline & Model & $\begin{array}{l}\text { Sum of } \\
\text { Squares }\end{array}$ & $\mathrm{df}$ & Mean Square & $\mathrm{F}$ & Sig. \\
\hline \multirow[t]{3}{*}{1} & Regression & 140.968 & 2 & 70.484 & 1.602 & $.208^{\mathrm{b}}$ \\
\hline & Residual & 3387.484 & 77 & 43.993 & & \\
\hline & Total & 3528.452 & 79 & & & \\
\hline
\end{tabular}

a. Dependent Variable: Financial Literacy

b. Predictors: (Constant), Math. Literacy, Gender

Table 3c. Coefficients Anareg

Coefficients $^{\mathrm{a}}$

\begin{tabular}{|c|c|c|c|c|c|c|}
\hline \multirow{2}{*}{\multicolumn{2}{|c|}{ Model }} & \multicolumn{2}{|c|}{$\begin{array}{c}\text { Unstandardized } \\
\text { Coefficients }\end{array}$} & \multirow{2}{*}{$\begin{array}{c}\text { Standardized } \\
\text { Coefficients }\end{array}$} & \multirow[b]{2}{*}{$\mathrm{t}$} & \multirow[b]{2}{*}{ Sig. } \\
\hline & & $\mathrm{B}$ & Std. Error & & & \\
\hline \multirow[t]{4}{*}{1} & (Constant) & 72.306 & 3.050 & & 23.707 & .000 \\
\hline & Math. & -.016 & .043 & -.043 & -.384 & .702 \\
\hline & Literacy & & & & & \\
\hline & Gender & 2.813 & 1.579 & .200 & 1.781 & .079 \\
\hline \multicolumn{7}{|c|}{ endent Variable: Financial Literacy } \\
\hline
\end{tabular}

Based on Table $3 b$ above, the sig value of 0.208 is greater than 0.05 , which means that at the $5 \%$ significance level the null hypothesis is accepted. This means that there is no simultaneous or joint 
influence between Mathematical Literacy and Gender on Financial Literacy. Partially the analysis is shown in Table 3c.

Based on Table $3 \mathrm{c}$ above, that is the sig value. for the variables of Mathematical Literacy and Gender respectively 0.702 and 0.079 greater than 0.05 , which means that Mathematical Literacy and gender partially do not have a contribution to Financial Literacy. Thus Mathematical Literacy and Gender do not have a contribution either simultaneously or partially to Financial Literacy. On the other hand there is a link between the context of Mathematical Literacy and Financial Literacy. The absence of contributions from Mathematical Literacy to Financial Literacy is allegedly due to the limitations of the questions developed to measure Financial Literacy, which only consist of 3 questions with content, function and algebra, and statistics and occupational, societal, and scientific contexts. On the other hand, Financial Literacy involves the context of education and work, home and family, individuals, and society.

Gender findings have no contribution to Financial Literacy supporting the results of the study (OECD, 2014) which shows that there is no difference in Financial Literacy between male and female students. Culturally there are differences in male and female student behavior, but because of the influence of age, parents education level, type of parents work, and living costs, the behavior of male and female students towards financial literacy is the same. A summary of the results of the Chi Square analysis is shown in the following table.

Table 4. Summary of Results of Chi-Square Analysis

\begin{tabular}{cccc}
\hline No. & Variable & $\begin{array}{c}\text { Asymptotic Significance } \\
(2 \text {-sided })\end{array}$ & Note \\
\hline 1 & Age & 0.042 & Significant \\
2 & Parental education & 0.024 & Significant \\
3 & Parental work & 0.237 & Significant \\
4 & Living cost & 0.036 & Significant \\
\hline
\end{tabular}

Male and female student behavior is influenced by age, parental education, parental work, and living costs. Age and cost of living of students are relatively the same, namely 18-20 years, and dominantly under 2 million. While the education level of parents is high school / equivalent at most, that is equal to $43.75 \%$ and the dominant type of work for parents is besides being a teacher, TNI / POLRI, office employees / entrepreneurship which is equal to $38.75 \%$. Furthermore, it can be said that age, cost of living, parents education level, and type of parents work are relatively the same, so this does not affect the differences in Financial Literacy.

\section{Conclusions}

Based on the previous description it can be concluded as follows.

- In general, mathematics literacy and financial literacy of UMESP students are medium classification

- Mathematical Literacy and Gender, both simultaneously and partially have no effect on Financial Literacy. Age, education level of parents, type of parents work, and living costs have a significant influence on gender.

Based on the above conclusions, it is suggested as follows:

- Other researchers, examined the problem of financial literacy by involving a wider population. 
- It is necessary to develop a model of financial mathematics courses as an effort to develop financial literacy for students

\section{References}

[1] Atkinson, A.; Messy, F. (2012). Measuring Financial Literacy: Results of the OECD / International Network on Financial Education (INFE) Pilot Study. OECD Working Papers on Finance, Insurance and Private Pensions. OECD Publishing. 15.

[2] Farah Javed and Samreen Lodhi.(2015). Financial Decision Making: Are Women Really Risk Averse?.International Journal of Informative \& Futuristic Research.3(3),907-920

[3] Haşmet Sarıül.2014. A Survey of Financial Literacy Among University Students. The Journal of Accounting and Finance., Oct(-),209-244

[4] Huston, S. (2010). Measuring Financial Literacy. Journal of Consumer Affairs. 44(2), 296-316

[5] Lemaster,P and JoNell Strough.(2014). Beyond Mars and Venus: Understanding gender differences in financial risk tolerance. Journal of Economic Psychology ,42 , 148-160

[6] Mahdiansyah dan Rahmawati (2014). Mathematical Literacy of Secondary Education Students: Analysis Using International Test Design with Indonesian Context. Badan Penelitian dan Pengembangan, Kemdikbud

[7] OECD [Organisation for Economic Co-Operation and Development] (2010). PISA 2012 Mathematics Framework. Paris: OECD Publishing

[8] OECD [Organisation for Economic Co-Operation and Development] (2013). PISA 2012 Assessment and Analytical Framework: Mathematics, Reading, Science, Problem Solving and Financial Literacy. Paris: OECD Publishing.

[9] OECD [Organisation for Economic Co-Operation and Development] (2014). PISA 2012 Financial Literacy Assessment Framework.Paris: OECD Publishing.

[10] OECD [Organisation for Economic Co-Operation and Development] (2016). Result from PISA 2015. https://www.bps.go.id/linkTableDinamis/view/id/1054 (diakses 31 Mei 2017)

[11] OJK [Otoritas Jasa Keuangan) (2016). Survei Nasional Literasi Dan Inklusi Keuangan 2016. Jakarta:-

[12] Suharta and Suarjana. (2018). A Case Study on Mathematical Literacy of Prospective Elementary School Teachers. Internatonal Journal of Instruction. 11(2), 413-424

[13] Wagner. DA. (2011). What happened to literacy? Historical and conceptual perspectives on literacy in UNESCO. International Journal of Educational Development .---,319-323. 